\title{
Supporting self-employment and small-scale entrepreneurship: potential programs to improve livelihoods for vulnerable workers
}

\author{
Yoonyoung Cho ${ }^{1^{*}}$, David Robalino ${ }^{1}$ and Samantha Watson ${ }^{2}$
}

\author{
* Correspondence: \\ ycho1@worldbank.org \\ ${ }^{1}$ World Bank and IZA, $1818 \mathrm{H}$ St \\ NW, Washington, DC 20433, USA \\ Full list of author information is \\ available at the end of the article
}

\begin{abstract}
This paper provides a review of the profiles of the subsistence entrepreneurs and their constraints, and the landscape of current entrepreneurship programs and the evidence on impacts, and discusses the potential role of public policies for the livelihoods of subsistence entrepreneurs. Worldwide over a half of workers are self-employed, but a significant fraction of these self-employed jobs are of low productivity subsistence entrepreneurs. The focus of the entrepreneurship programs to support these self-employed in poverty is to improve their livelihoods rather than promoting cutting-edge innovation and business growth. Evidence of successful programs is limited and program designs often seem ill suited to the needs and characteristics of these subsistence entrepreneurs. Given the market failures faced by subsistence entrepreneurs, interventions that complement safety net programs with well-targeted support to promote productive self-employment may hold some promise.

Jel codes: $012,016, J 24$

Keywords: Entrepreneurship programs; Subsistence entrepreneurs
\end{abstract}

\section{Introduction}

Worldwide around 55 percent of workers are self-employed, and about three-quarters of these are likely to be subsistence entrepreneurs (Gindling and Newhouse, 2014). These self-employed workers include farmers and own-account workers, many of whom presumably work in small household enterprises without pay. A large proportion of these workers live in poor or vulnerable households. In Sub-Saharan Africa, for instance, close to 80 percent of the self-employed are poor as will be discussed below. ${ }^{1}$ While numerous countries have adopted programs that aim to promote selfemployment and entrepreneurship, the design of such programs seems ill suited to respond to the needs of those who engage in entrepreneurial activities not by choice, but by necessity.

This paper discusses the potential public policy role of programs aimed at improving the livelihoods of subsistence entrepreneurs. Subsistence entrepreneurs refer to those who are self-employed out of necessity and who often lack skills and entrepreneurial traits. ${ }^{2}$ Therefore, they are different from other types of entrepreneurs who are selfemployed with new ideas and risk taking attitudes with growth orientation. ${ }^{3}$ The paper 
begins by looking at the characteristics of self-employed workers, the different types of entrepreneurs, and the constraints they face. It then analyzes the potential role of public policy in improving the earning opportunities of subsistence entrepreneurs, the types of programs that could be used, and general issues to be considered when designing and implementing pilot interventions. The focus of the programs to support subsistence entrepreneurs would be to improve their livelihoods and reduce poverty as opposed to promoting cutting-edge innovation or growth.

The paper has four main messages. First, in the context of a global strategy to increase the incomes of the poorest workers, it is important to identify interventions to support subsistence entrepreneurs. The constraints they face and the type of support they need differ from those of vocational or transformational entrepreneurs. Second, the evidence of what works for subsistence workers is limited. A few programs have been successful, but they tend to be small, and there is limited knowledge available about design and implementation in different contexts and with different types of beneficiaries. Third, given prevalent market failures faced by the poor, interventions to complement safety net programs and improve the livelihoods of subsistence entrepreneurs are required. Fourth, going forward, it is critical to adopt a more systematic approach to designing, implementing, and evaluating new programs. Special attention should be paid to eligibility, targeting, and profiling mechanisms; selection of businesses to be supported; adaptation of core interventions (training, access to finance, advisory and mentoring services, and networking) to beneficiary needs; whether and how programs are integrated into subsectors and/or value chains; and delivery mechanisms for different services.

\section{Understanding self-employment and the role of public policy}

\subsection{Who are the self-employed?}

Most workers in middle- and, particularly, low-income countries are self-employed: either farmers or own-account workers in nonfarm activities (Fig. 1a). The share of workers in agriculture drops as a country's income per capita increases. Even in the average middle-income country, however, around half of workers are self-employed, and three-quarters of the non-agriculture jobs are own-account work. In Sub-Saharan Africa and South Asia, for instance, where the large majority is self-employed, about 20 percent of the employed are own-account or unpaid workers outside agriculture, and more than half are agricultural workers (Fig. 1b).

Individual characteristics such as education, age, and gender are important determinants of employment status including self-employment. Gindling and Newhouse (2014), based on household data from over 100 countries $^{4}$ examined the characteristics of the developing world's self-employed. The main descriptions are as follows: ownaccount workers and agricultural workers have low educational outcomes, while employers and wage workers tend to be better educated; self-employment tends to become more common with age, with an exception of countries in Sub-Saharan Africa particularly in agriculture where the majority of young workers find opportunities from selfemployment; gender effects also tend to be country specific with women are more likely to be self-employed than men in Sub-Saharan Africa and South Asia unlike in Europe and Central Asia and in Latin America and the Caribbean. 
a. by per capita GDP

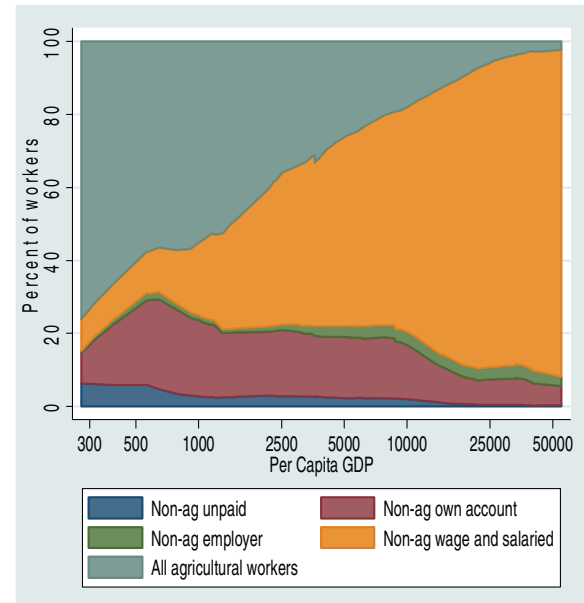

b. by region

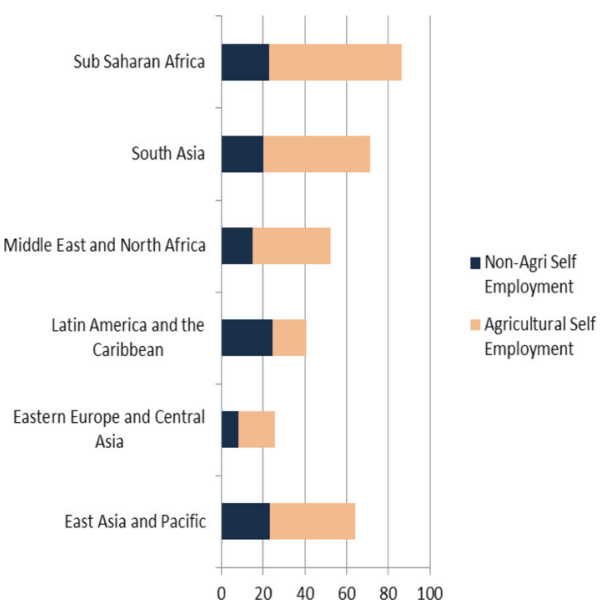

Fig. 1 Proportion of workers who are self-employed. a By per capita GDP. b By region

Many of the self-employed worldwide, subsistence or severely constrained entrepreneurs, live in poor households (Fig. 2). Given that households often have more than one self-employed individual, the high prevalence of poverty attests to the low level of productivity and earnings of these businesses and activities, particularly in agriculture. Clearly, there are important differences across regions which reflect the income level of the countries. In Sub-Saharan Africa, 80 percent of the self-employed live in poor households, compared to only about 20 percent in either Europe and Central Asia or Latin America and the Caribbean.

Studies examining the mobility of workers by examining panel data sets suggested that employment status was not static and that among less successful entrepreneurs (own-account workers), there are some that have the characteristics of the more successful (employers). ${ }^{5}$ For instance, a non-negligible proportion of own-account workers have seemingly similar characteristics to employers, and similarly employers have many

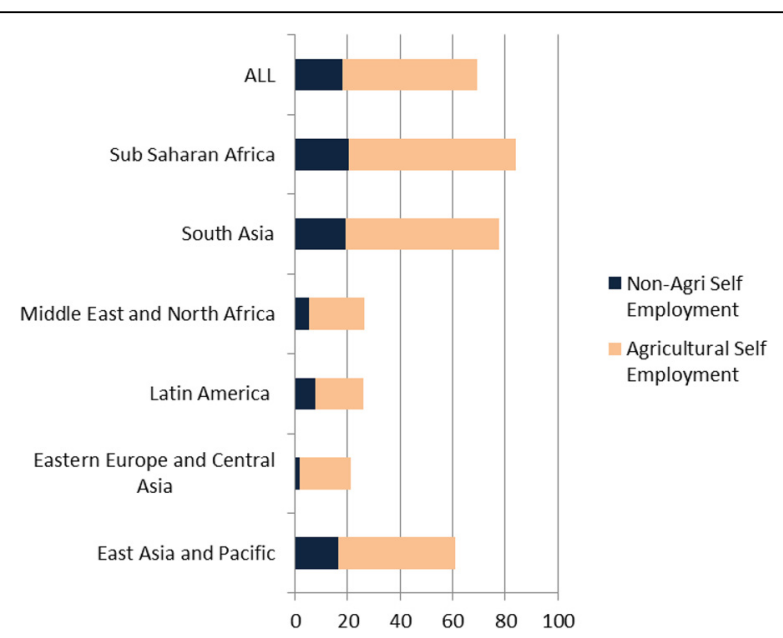

Fig. 2 Rate of poverty among the self employed. Source: Gindling and Newhouse 2014 
observable attributes in common with own-account workers. ${ }^{6}$ In general, the literature suggests that different types of entrepreneurs-for example, transformational, vocational, and subsistence entrepreneurs-coexist. ${ }^{7}$ They often differ by their capital and skills (Nguimkeu, 2014; de Mel et al. 2008).

\subsection{What are the constraints facing the self-employed and small-scale entrepreneurs?}

Potential constraints and factors that may affect productivity and earnings can be classified in two groups: individual and environmental (Table 1). Individual constraints include lack of entrepreneurial aptitude and traits, as well as skills and social capital. Environmental constraints include limited access to financial services and products, an adverse business environment, underdeveloped markets for inputs and outputs, and other impeding cultural factors. Even if the market and regulatory failures that create environmental constraints could be removed, the lack of aptitude, skills, and cognitive abilities to understand, discover, and develop business opportunities traps subsistence entrepreneurs in a low-level productivity equilibrium. Therefore, the discussion below is limited to individual constraints, which tend to be the focus of Self-employment and Small-scale Entrepreneurship (SSE) programs. (See Additional file 1 for a full list of assessment tools by type of constraint.)

\subsubsection{Aptitude}

Several interlinked attributes, such as personality, aspiration, and noncognitive skills, fall in the category of entrepreneurial aptitude or traits. A large volume of literature argues that entrepreneurial aptitude is an important determinant of business success (For instance, Rauch and Frese 2000). The following personality traits are associated with being successful in business: innovative, imaginative, creative, flexible, adaptable, reliable, responsible, self-reliant, and calculated risk-taking (Develi 2011). The Big 5 Personality Test and the Pearlin and Schooler scale (the locus of control or self-efficacy) are examples of tools commonly used to assess personality or noncognitive skills. Aspiration is related to entrepreneurs' motivation to create new products, innovate,

Table 1 Individual and environmental constraints to entrepreneurship

\begin{tabular}{ll}
\hline Individual constraints & Environmental constraints \\
\hline Aptitude & Financial services \\
Personality (noncognitive skills) & Availability of banking service \\
Aspiration and preferences & Access to credits/loan \\
Skills & Financial management tools (e.g., debit/credit card) \\
Basic skills & Local business environment \\
Technical skills & Regulatory and legal environment \\
Business skills & Government capacity (corruption) \\
Financial capability & Infrastructure \\
Noncognitive skills (personality) & Access to markets \\
Social capital & Cultural factors \\
Networks, associations & Attitudes and norms \\
& Social class/status/gender \\
\hline
\end{tabular}


achieve, and grow a business. According to the Skills Towards Employability and Productivity (STEP) skills measurement surveys, the top 25 percent of self-employed earners have different socio-emotional skills: they are less likely to make decisions carefully and tend to take risks. ${ }^{8}$ Self-employed workers who are entrepreneurs by necessity and for subsistence are often deemed to lack entrepreneurial aptitude. There is still a limited understanding of how these traits are formed and affect behaviors. However, an assessment of entrepreneurial traits can potentially inform the targeting or design of SSE programs.

\subsubsection{Skills}

The ability of individuals to develop a business activity, solve problems, take financial decisions, manage risks, or find clients depends on their skills as well as their aptitude. Basic numeracy and literacy skills seem to be a precondition to setting up and operating a business, but these skills are often lacking, particularly among subsistence entrepreneurs. Partly because education levels are low, their cognitive skills tend to be underdeveloped. Low levels of cognitive skills affect the capacity of individuals to interpret and process information about events that can affect their business and require strategic actions. Low cognitive skills also limit the capacity to choose viable economic activities in the first place and to learn from failure or success (Heckman et al. 2006). In Ghana, for instance, about 80 percent of workers with lower secondary education self-report that they are literate, but only 50 percent pass the core reading test because they lack a sufficient level of literacy (Pierre et al. 2014; Valerio et al. 2014c).

Technical skills are critical in many jobs-such as a tailor's skills to make and repair clothes, or a farmer's skills to operate machinery. Many workers acquire such skills through informal arrangements, learning from family or friends or by working at local workshops. Building these skills and maintaining up-to-date techniques can be a challenge for some workers. In the region of San Gregorio, Ecuador, for instance, many workers are engaged in the cultivation of balsa wood. Reported mortality rates of the young trees, however, are over 50 percent because the workers are using outdated planting techniques and do not implement schemes to address the most common predators. Such examples of inadequate skills are commonplace in developing countries, particularly in remote areas.

Skills are also lacking with respect to basic principles of business and finance. Business skills enable individuals to manage sales and marketing, human resources, customer relations, accounts, and information and communication technologies. A few recent studies (e.g., Bloom and Van Reenen 2010; Bruhn et al. 2010) have emphasized business skills and managerial capital as a key factor in successful entrepreneurship. A survey in Uganda, for instance, shows that managerial weaknesses such as incorrect pricing, poor recordkeeping, inadequate inventory control, and faulty product concept are among the self-rated causes of small business failure (Tushabomwe-Kazooba 2006). Moreover, a lack of financial capability substantially limits the ability to operate a business, particularly over a longer term (Holzmann, Mulaj, and Perotti 2013). Along with low education and limited access to financial products, a lack of financial skills often exposes entrepreneurs to mismanagement of cash flows, overindebtedness, and scams and fraud. 


\subsubsection{Social capital}

Social capital refers to the institutions, relationships, and norms that shape the quality and quantity of a society's social interactions. When it comes to business, social capital is the primary resource entrepreneurs may rely upon to find new business opportunities, manage resources, and secure legitimacy from external stakeholders (Stam et al. 2013). In particular, the role of social capital in facilitating access to credit among the poor in developing countries has been widely recognized. ${ }^{9}$ India's Self-Employed Women's Association is a good example of how social capital can assist self-employed women in connecting to information, markets, and financing.

\subsection{What could be the role of public policy for subsistence entrepreneurs?}

Whether governments should intervene to improve the earnings and livelihoods of subsistence entrepreneurs through entrepreneurship programs is, in the end, a question about the social benefits and costs of the intervention. One strand of research suggests that programs to promote entrepreneurship should target individuals with the highest growth potential, with sufficient cognitive skills and entrepreneurial aptitude. This implies that the support subsistence entrepreneurs could receive would be limited to antipoverty transfers and probably interventions to connect them to wage employment. When wage employment is lacking, however, safety nets alone will not lead to a sustained increase in earnings and living standards. At the same time, it might be possible-and examples do exist-to have SSE programs that generate social benefits greater than social costs. These benefits would include increasing incomes and consumption levels above what could be achieved through safety nets, and reducing safety net expenditures and their associated opportunity cost. In addition, there can be positive externalities resulting from potentially higher investments in human capital.

One set of programs would aim to improve the earnings generated by current activities, without attempting to change the nature of the work or individual traits. This outcome would be possible by improving pricing mechanisms, product quality, and production technologies to reduce costs and/or increase output and/or quality; or by expanding markets. Many subsistence farmers, for instance, could be better off simply by having access to better seeds, better products to protect their crops, and appropriate technology-even if their production is only for household consumption and does not generate external employment. Thus, interventions with the potential to increase the earnings of the self-employed are possible, without expecting subsistence entrepreneurs to change into vocational or transformational entrepreneurs. Such interventions include efforts to improve knowledge and upgrade technology, facilitate better access to equipment and inputs, and offer better opportunities to price and sell products. Some recent or ongoing experiments (e.g., Conley and Udry 2010; Gine and Yang 2009) are particularly concerned with finding good mechanisms to upgrade skills and facilitate the adoption of new technology.

More complex interventions would require changes in the organization of a given business, aiming to facilitate entrepreneurs to engage in more transformative activities and/or to be integrated into value chains. Farmers, for example, could be involved in a processing business of their basic produce: trees into wood planks, fruits into frozen pulp or conserves and animals into meat. By bringing several small farmers or crafts 
people into associations or cooperatives and increasing production volumes, the resulting groups could take advantage of economies of scale and the local, regional, or national value chains often found in specific sectors such as food products, tourism, and textiles. For this type of intervention, it is reasonable to envisage that third parties with the necessary technical expertise-either for-profit or nonprofit entities-could develop the business plans and manage the implementation, including mobilizing the necessary resources and expertise. Many of these opportunities might not be exploited because of low expected private rates of return on investments with high associated risk, lack of local knowledge, coordination costs, or regulatory failures. The role of the public sector would be to facilitate the emergence of business that integrates subsistence entrepreneurs into more lucrative and transformative activities, including by ensuring access to skills, credit/grants, and basic infrastructure.

\section{What programs exist to promote self-employment and small-scale entrepreneurship?}

An inventory of 106 SSE programs, including both organizational approaches and specific entrepreneurship projects across all six World Bank regions, that aim to improve the earnings opportunities for self-employed workers was constructed. The inventory documented characteristics of SSE programs, supplemented by interviews with practitioners and experts. An emphasis was placed on programs that target the self-employed and businesses with 10 employees or fewer. Some programs discussed here are organizational approaches such as curricula or tools for entrepreneurial training that are adaptable to various projects (e.g., the International Labour Organization's Know About Business initiative). Others are projects with heterogeneous implementation details. The inventory was drawn from three sources: (1) the Entrepreneurship Education and Training (EET) database created by the World Bank Team, ${ }^{10}(2)$ the Youth Employment Inventory database ${ }^{11}$; and (3) relevant World Bank projects with "entrepreneurship" and "self-employment" as keywords in the main stated objectives. In selecting programs for the inventory, the focus was on programs that directly address constraints of individual beneficiaries with respect to business activities as opposed to indirect approaches-such as the construction of business infrastructure, capacity building of financial institutions, or the facilitation of financial inclusion without the promotion of business activities. The inventory, although it may not be the universe of the SSE programs, presents the landscape of current programming in this area by capturing the main approaches and project across all six regions (see Fig. 3a for regional distribution of the programs). There were large variations in terms of design and implementation arrangements. Overall, the review suggests that many existing programs are unlikely to be suited to the needs of subsistence entrepreneurs.

\subsection{Targeting, eligibility, and selection}

Definition, identification, and selection of beneficiaries are often the greatest challenge in program design. The general trend, in both organizational approaches and projects, is toward open beneficiary groups with demand-driven services, targeting mainly existing entrepreneurs; around 79 percent of organizational approaches and 58 percent of projects target this group. Programs often target a broad group by including micro, 


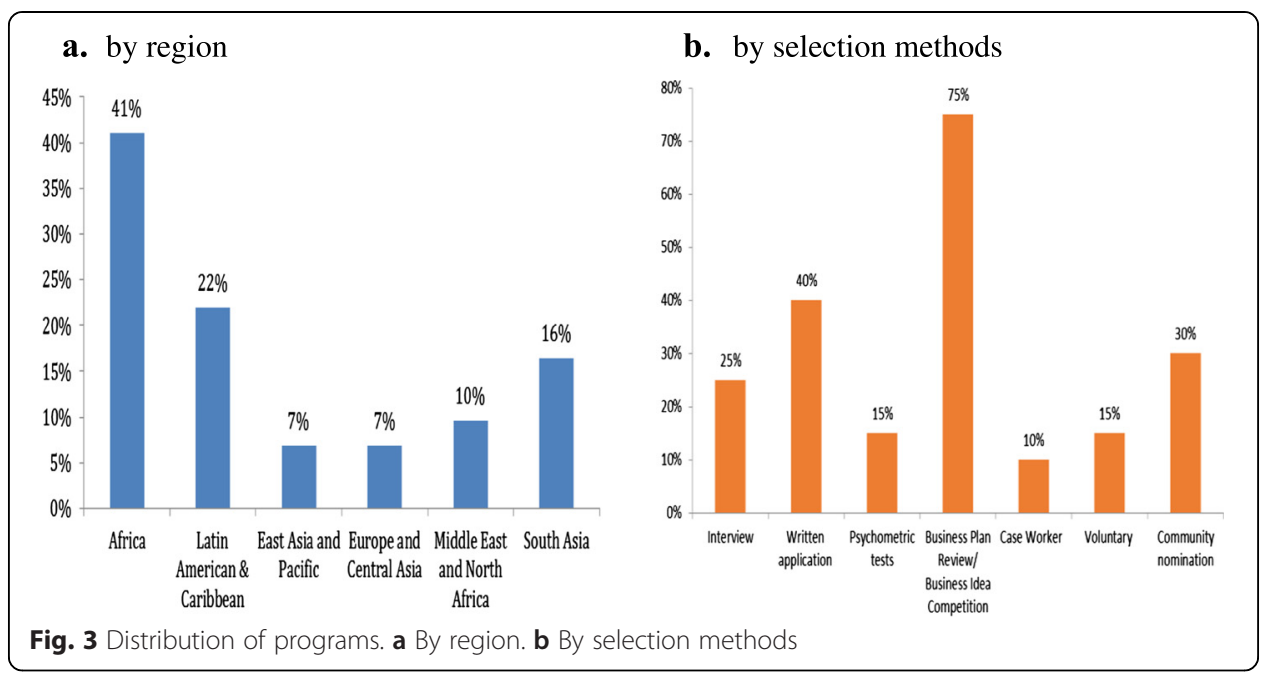

small, and medium-size enterprises with more established entrepreneurs coveredsuggesting that subsistence entrepreneurs are largely excluded from public intervention.

Targeting based on the characteristics of potential beneficiaries (such as age, education, gender, or income level) is not prominent among the SSE programs in the inventory. For instance, 32 percent of the projects focus solely on women, while the rest include both genders. Similarly, programs that are exclusive to youth are not numerous; about a quarter of projects target this group. Although projects often recognize the greater needs among women and youth and utilize gender- or age-specific quotas or mobilization methods (e.g., women's associations, youth groups, community nomination, or outreach campaigns), SSE programs tend not to use demographic targeting. Surprisingly, education or skills levels also are not often part of targeting criteria, and only 25 percent use education levels in eligibility. Some assessment of skills-whether using education as a proxy or directly testing beneficiaries-is likely to help customize the design of SSE programs to participant needs. Further, few programs explicitly target the poor or beneficiaries of safety nets. ${ }^{12}$ This finding suggests that SSE programs may currently overlook the most vulnerable group of workers who could benefit from such programs the most.

It is not clear what methods programs use to select beneficiaries within the defined target group; in fact, only 20 projects in the inventory report their selection methods. Among these programs, business plan review/competition is most frequently used, followed by written applications and community nomination (Fig. 3b). Several programs report that business plan review/competition, written application, or interview selection methods often serve as a tool to assess and identify constraints in addition to screening applicants when targeting entrepreneurs with limited skills and education. Recently, a handful of programs have begun using psychometric tests that discern some entrepreneurial traits as part of their selection process. The World Bank's Women Entrepreneurship Development Project in Ethiopia, for instance, in collaboration with Harvard's Entrepreneurial Finance Lab Research Initiative, is testing a psychometric measure of assessing credit for selecting participants for access to finance. If proven effective, such tests will allow commercial banks to assess the credit worthiness of lowerincome individuals who lack collateral and credit. 


\subsection{Technical components}

Program services were classified into four technical components: training, access to finance, advisory and mentoring services, and networking. The majority of programs provide combinations of these services: the vast majority of organizational approaches and nearly three-quarters of projects provide some combination of multiple services. The number of services combined in a program varies across regions. For instance, about 75 percent of programs in the Latin America and the Caribbean region provide two services or less, compared to the Sub-Saharan Africa and South Asia regions where over 40 percent of programs provide three to four services. This finding probably reflects the fact that individuals in lower-income countries are more likely to be affected by multiple constraints. Similarly, when looking at implementation arrangements, projects implemented jointly by the public and private sectors are more comprehensive than those delivered solely by either private or public service providers.

Training is by far the most commonly offered service. Conversely, direct provision of access to finance is the least prevalent service offered, with only 30 percent of the projects reviewed providing it. Instead, many programs (67 percent of organizational approaches and 60 percent of projects) report that they link beneficiaries to outside financial services. Projects that involve the private sector for service delivery are more likely to provide access to financial services than purely publicly implemented projects: 28 percent of public projects, 32 percent of private projects, and 46 percent of combined public-private projects provided direct access to finance. The low utilization of access to finance in the programs reviewed may reflect the fact that the main objective of financing projects such as microcredit programs is often consumption smoothing without promoting entrepreneurial activities. Over half of the programs reviewed provided the two remaining services-advisory services and mentoring and networking.

\subsubsection{Training}

Training is a key method for building entrepreneurial capacity. About two-thirds of the projects in the inventory use traditional classroom-based training; workplace training, including apprenticeships and on-the-job training, is used in 26 percent of the projects. There is great variety across programs in terms of training intensity and duration. In fact, some programs literally customize trainings to each group, without having a standard approach even within the program. Among the many topics covered in SSE programs, business-related training predominates, including business planning, general business and marketing skills, and financial literacy and capability (Fig. 4a). Foundational skills training such as numeracy/literacy or vocational training is less prevalent. In Latin America and the Caribbean, vocational training is particularly low, with only 6 percent of programs providing such content. South Asia, on the other hand, is the most likely to provide vocational content, with half of the programs that include training addressing vocational content.

\subsubsection{Financial services}

As mentioned above, only 30 percent of the projects reviewed have a component that directly provides access to finance, while 60 percent link beneficiaries to outside 


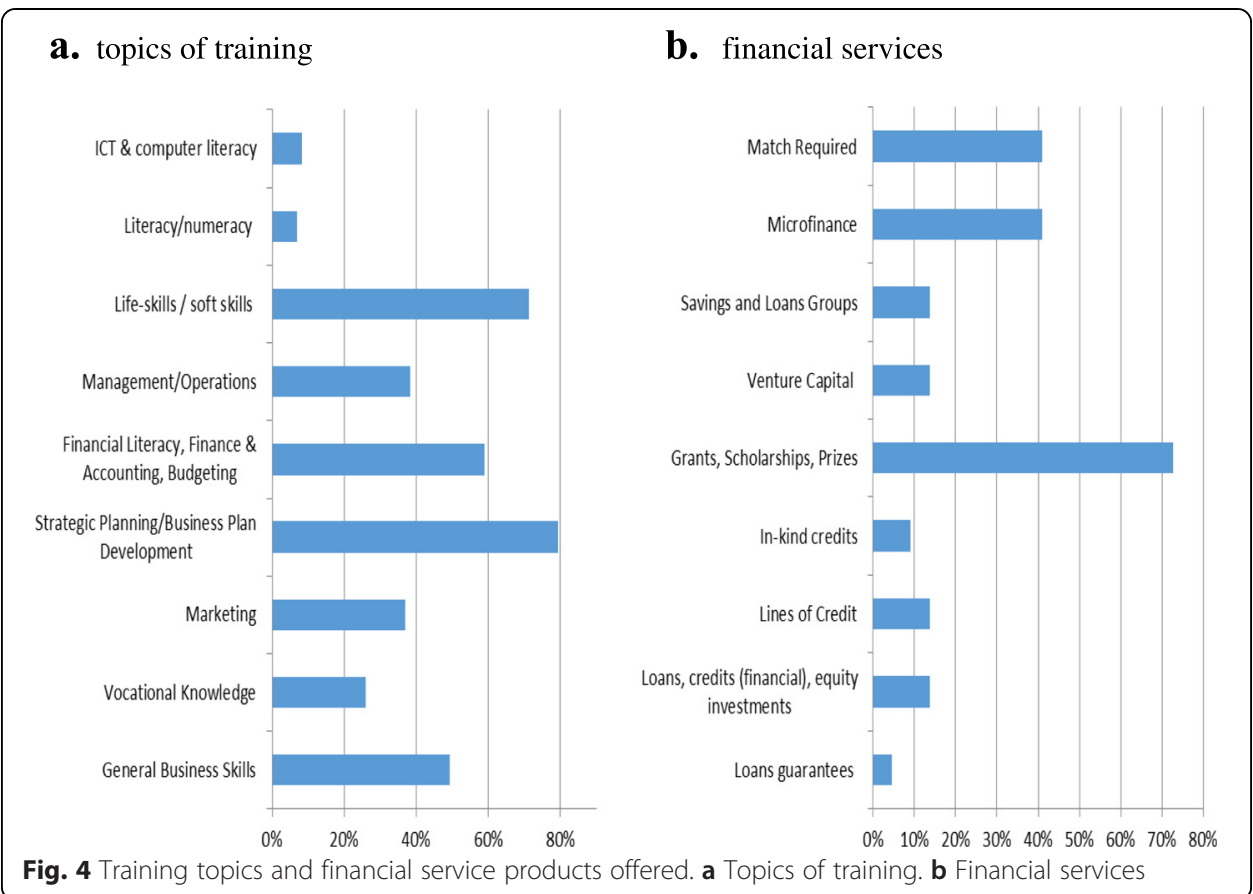

financial services. Figure 4b shows the specific types of direct financial products programs provide. Cash grants, scholarships, and prizes are the most common form of financial support, followed by microfinance. Sixty-three percent of the programs providing access to finance in Sub Saharan Africa, 100 percent of those in Latin America and the Caribbean, 67 percent of those in South Asia, and 86 percent of those in the other regions provide grants, scholarships, and prizes. Meanwhile, savings and loans group, as well as microfinance tend to be concentrated in Asia.

Matching grants and loans that require the beneficiary to provide materials, investment, or cash up to a certain percentage of the loan/grant amount appear to be common: 40 percent of all programs providing access to finance require matching. The model is based on the belief that matching funds-even if only a small amount-helps ensure that the beneficiary is equally invested in the business. Match requirements on financial services are more prevalent in Latin America and the Caribbean and in South Asia (67 percent and 50 percent, respectively) than in the other regions (under 40 percent).

Different models for matching grants exist. The Economic Empowerment of Adolescent Girls and Young Women project in Liberia (AGI Liberia) and the Vocational Training for Youths with Disabilities in Western Area and Kono Districts project of Sierra Leone provide grants to encourage participants to save; the programs match any savings the participants accrue during their participation with a seed grant to start their business. Other programs use matching grants to match any outside capital an entrepreneur can access. The Entrepreneurship Program for Innovation in the Caribbean (EPIC) is an example of this model. Still other programs require entrepreneurs to invest what they already have into the business as a show of commitment. The Congo-Support to Economic Diversification Project uses this model and requires participants to put up some 10-20 percent of the financing. 


\subsubsection{Advisory services and networking}

Advisory services include technical assistance and mentoring, while network interventions help provide entrepreneurs with linkages to peers and potential clients. Technical assistance is defined as advice based on particular business issues or on the circumstances of the entrepreneur. Mentoring implies a closer relationship and can include counseling on more personal and nontechnical issues. In some cases, technical assistance and mentoring are provided together.

With respect to networking, horizontal networking is the most common type of support. Group business organizations, forums, and study tours to establish networks are frequently used tools. The National Rural Livelihoods Project in India provides a good example of horizontal linkages that enable the many to achieve more than any individual could. Specifically, the project encourages the formation of savings groups that seek to overcome banks' reluctance to work with small entrepreneurial activities by combining assets; members submit a joint financing request and repayment plan to banks. Through these linkages, more rural businesses are able to access finance. Not surprisingly, a higher percentage of programs targeting potential entrepreneurs provide networking services (62 percent) than those targeting existing entrepreneurs (48 percent).

\subsection{Institutional arrangements}

Implementation arrangements vary across the programs reviewed. The public sector remains the largest funder for these programs, although some private sector funding complements and supports several initiatives. More heterogeneity exists with regard to implementing agency. Private sector entities such as nongovernmental organizations (NGOs) or contracted service providers are the main implementers in over a third of the projects reviewed. An additional 12 percent are implemented by a combination of private and public sector providers. Quite a high proportion of projects (40 percent) report direct service delivery by public agencies; this can be a limitation in low-income settings where resources and institutional capacity are lacking. As noted earlier, some variation exists in how programs are structured depending on the implementation arrangements.

Very few programs provide relevant information on program costs. The available information (based on 10 projects in developing countries in the inventory) suggests that there is considerable heterogeneity across programs. ${ }^{13}$ For instance, known cost per beneficiary ranges from $\$ 95$ (Women's Enterprise Management Training Outreach Program in India) to $\$ 1,200$ (AGI Liberia's business development track). This range reflects many factors, including variety of services provided, program comprehensiveness, different methods of calculating cost per beneficiary, and variations in geographic pricing. With no standard method for calculating unit costs, few programs providing information on costs, and difficulty in measuring social costs and benefits, little is known about the cost-effectiveness of each program.

\subsection{Trends in evaluation}

Monitoring and evaluation systems are generally weak. Currently, only 7 of the organizational approaches and 36 of the projects reviewed had conducted rigorous evaluations. Impact evaluations are more prominent in the Latin America and the 
Caribbean region, with 69 percent of the region's programs having rigorous evaluations, in comparison with 37 percent and 33 percent in Sub-Saharan Africa and South Asia, respectively. For the remaining three regions, 41 percent of programs have rigorous evaluations. Globally, the rigor of evaluations seems to vary with implementing agency. Half of the programs implemented solely by the private sector have rigorous evaluations, compared to 41 percent of publicly implemented programs and 38 percent of those implemented jointly by the public and private sectors.

Related to the weak monitoring and evaluation system, many programs tend to focus on output indicators (e.g., number of beneficiaries trained, number of toolkits dispersed) rather than outcome indicators. Several do track outcome indicators, including: labor market activities (e.g., employment), income (e.g., profits/earnings), business knowledge and practice (e.g., bookkeeping), business performance (e.g., sales), financial behavior (e.g., loan take-up), attitudes (e.g., confidence), and others (e.g., indicators capturing the result of regulation reform or public infrastructure investments). Not surprisingly, the most frequently tracked outcomes of interest include business performance such as sales, number of paid employees, or inventory amounts.

\section{What do we know about impacts?}

There is limited evidence regarding the impacts of entrepreneurship programs, and the results are mixed. Recently, studies (e.g., Cho and Honorati 2014; Grimm and Paffhausen 2015) have conducted meta analyses and synthesized the impacts of entrepreneurship programs on various outcomes focusing on labor market activities and performance. Cho and Honorati (2014) found that of the programs reviewed that have been evaluated, only around 30 percent have had positive results, but the size of these impacts is usually small. What seems clear from both studies is that stand-alone interventions-especially access to credit on its own-are less likely to make a difference. This finding suggests that targeted beneficiaries face multiple constraints, and effective programs may need to integrate several services.

The likelihood of having positive impacts and the size of impacts vary widely by outcomes of interest. Current evaluations suggest that business knowledge and practice, such as recordkeeping, registration, and separation of individual and business accounts, are relatively easy to change compared to other outcomes (McKenzie and Woodruff 2014; Cho and Honorati 2014). Thus, interventions such as business training work relatively well for existing entrepreneurs. However, improved business knowledge and practice do not necessarily translate into business growth or increased profits (e.g., Karlan and Valdivia 2011). This finding may be related to the timing of post-intervention survey, since the period between program completion and the survey is typically short, and the impacts for final outcomes may not be fully materialized.

Regardless, business training programs are quite heterogeneous both in terms of design and impact. The target group for business training ranges from the rural selfemployed to urban small and medium enterprises, and their content, duration, intensity, and survey timing are equally diverse (McKenzie and Woodruff 2014). Although business training improves the survival of existing enterprises and facilitates new business start-up, more evidence is needed regarding best practices in pedagogical approaches and implementation arrangements. For instance, a study suggests that business training based on "rule of thumb" rather than on sophisticated and difficult lessons 
may be more effective, specifically for the most vulnerable subsistence self-employed (Drexler et al. 2011). Also, follow-up services beyond in-class business training to provide technical assistance tailored to individual needs can further improve impacts (McKenzie and Woodruff 2014).

Compared to business knowledge and practice, it is more difficult to change labor market outcomes including employment levels, hours worked, and-certainly-earnings. In general, programs providing training combined with financing or counseling seem to perform better in promoting labor market activities, particularly for youth (Cho and Honorati 2014). Vocational training combined with grants in Nicaragua for social safety net beneficiaries is an example of such a program (Macours et al. 2012). Grants provided to vulnerable youth so that they could pursue vocational training in Uganda also yielded positive outcomes (Blattman et al. 2014). Conversely, training or financing provided alone may not be sufficient to address the complex constraints faced by microenterprise owners in developing countries. A recent review by the Consultative Group to Assist the Poor of largely stand-alone financing interventions found few impacts regarding business performance and labor market outcomes (Bauchet et al. 2011). There is little evidence of any difference in effectiveness between cash, in-kind grants, and microcredit schemes.

Overall, the impacts of interventions tend to be weaker for women: capital infusion for microenterprises has had great returns for men but not for women in Sri Lanka and Ghana (de Mel et al. 2009 and Fafchamps et al. 2011, respectively) ${ }^{14}$ and the impacts of apprenticeship training are weaker for girls than boys in Malawi (Cho et al. 2013). Women may face more stringent constraints in skills acquisition and business operation, and control over finances often reverts to men even if women are business owners or recipients of microcredits. ${ }^{15}$ These results suggest that programs need to be better tailored to address the constraints facing self-employed females. A successful example is the business development track of AGI Liberia program. ${ }^{16}$ This initiative specifically targeted young women and provided training in the locality in which they resided (taking into account their mobility constraints), and included free child care (addressing their family responsibilities). These considerations may help explain the program's success.

The chief conclusion emerging is that there is still limited knowledge about the specific design and implementation features that make a program successful for a given population group and in a given context. Additionally, the fact that many of the programs evaluated are small pilots raises questions about external validity and the potential for scaling up-a particular concern for programs that support businesses that operate in small local markets. It is also important to note that the evaluations provide little information about program sustainability. Even where there are positive effects on employment and earnings, these might be short-lived given the high mortality rate of entrepreneurial activities.

A few questions related to targeting, design, and implementation remain to be further researched:

- Targeting versus design. Do programs fail because they have targeted the wrong beneficiaries-i.e., the self-employed who have little growth potential? Or do programs fail to adapt the design to respond to the needs of the type of 
beneficiaries targeted? While great efforts have been made to identify individuals with better prospects for business growth, relatively little attention has been paid to finding the right intervention for subsistence entrepreneurs. Many of the SSE programs reviewed seem to deliver the same kind of business support developed for small and medium-size firms as opposed to providing support tailored to the specific needs of self-employed workers.

- Design versus implementation. Even if a program is well designed with technical components appropriate to the situation and participants, it is likely to yield little impact if not well implemented. Seemingly similar programs can work in one place but fail in another. Proving the external validity of certain approaches is difficult due to heterogeneous implementation arrangements. The review suggests that many programs are still provided directly by governments/public sector. Yet, better programs seem to be delivered by local NGOs or community-level institutions, which are more likely to be familiar with beneficiary needs and constraints. In future programming, process evaluations should be prioritized along with impact evaluations to gain insight into design versus implementation questions.

- Constraints versus complaints. Programs often rely on self-reported surveys to identify serious barriers to productive entrepreneurship. Limited access to finance is among the top constraints. However, limited evidence of financing services on entrepreneurial outcomes suggests that limited access to finance might simply be a common complaint. Many other impeding constraints may exist that are as important as limited access to finance. There is a great need for improving tools that provide objective information about individual and environmental constraints.

\section{General considerations in the design and implementation of programs to support subsistence entrepreneurs}

The livelihoods of those engaged, or who can engage, in self-employment or smallscale entrepreneurship as a subsistence activity could be improved through SSE programs. The objective of such programs would not be to identify "gazelles" and help them grow, but to support those who are engaged in subsistence activities even if they lack growth potential. The implication is that government interventions should be properly evaluated. Only after understanding their impacts, implementation challenges, and costs, can decisions be made in order to adjust and scale-up effective programs. There are four areas of program design that need to receive attention: (1) targeting, eligibility criteria, and beneficiary profiling; (2) identifying and selecting business activities; (3) defining core interventions; and (4) choosing delivery options for various program components.

\subsection{Targeting, eligibility criteria, and beneficiary profiling}

The target group for SSE programs would be individuals-not firms-who are, or who can become, self-employed in, generally, low-productivity/low-earning activities. They are either poor or live in households with consumption levels close to the poverty line. They can be engaged in subsistence farming, nonfarm activities in rural areas, or produce goods and services in urban areas. Often self-employment may not be their main, 
or at least not their only, activity; they can be involved in more than one type of business. Within this large set, governments should define priorities based on policy objectives and could include eligibility criteria such as age, gender, or geographic region.

While some studies have investigated a mechanism through which high growth potential entrepreneurs could be identified and targeted for benefits (Fafchamps and Woodruff 2012), such approach may not reach the most vulnerable group that public policy aims to target. In order to maximize the poverty reduction impacts of SSE programs through entrepreneurial activities, the same mechanisms used to target social assistance programs can be used. These mechanisms include combinations of geographical and categorical targeting, proxy means tests, and community participation. In many cases, the entry point to SSE programs can be existing safety net programs where SSE is linked as part of a graduation strategy.

Even after identifying and targeting the potential beneficiaries, designing programs to fully benefit the vulnerable groups is challenging. One issue involves the low take-up rate, which has become an ubiquitous observation among the poor across many different sectors in developing countries. Examples of low take-up include underutilization of insecticide-treated bed nets (Ashraf et al. 2010), improved cookstoves (Duflo et al. 2012), insurance or savings (Mobarak and Rosenzweig 2012), and fertilizers (Duflo et al. 2011). Low take-up may indicate that the returns are highly heterogeneous across different beneficiary groups and that programs are not suitable for a subset of the population, particularly for vulnerable groups faced with complex constraints. In addition, the track record of the impacts of such programs is not strong as extensively discussed in the previous section.

Profiling and understanding the skills, capabilities, and constraints facing potential beneficiaries is, therefore, critical to the design of programs that are able to serve the vulnerable. The profiling method will depend on the context, but it is likely that survey instruments and objective indicators are cheaper and more reliable than the more subjective assessments of program managers, counselors, or expert groups. ${ }^{17}$

\subsection{Identifying and selecting business activities}

There are two approaches to identifying business activities. A participant-driven model, which is similar to that used in traditional entrepreneurship programs, is one in which individuals select their business and join the program. The other model is project identified. In this model, the project identifies, ex ante, profitable business activities in a region or sector through some type of assessment and guides participant start-up activities to the selected industry or business type. Both methods have pros and cons and are likely to be more relevant to some groups than others.

\subsubsection{Participant driven}

In this approach, participants self-select into a program usually by applying for support, submitting a business plan or idea for review, or participating in offered services. Among those who already have an idea about a business or who operate actual businesses, beneficiaries are selected and support provided. Selection methods to determine beneficiaries among applicants, in case of oversubscription, include first come, first served; objective criteria including psychometric tests or randomization; and selection 
by committee based on interviews or business proposals. Depending on beneficiary needs, support packages can then be designed. Programs following this approach include AGI Liberia and the Women Entrepreneurship Development Project in Ethiopia (Table 2).

This is a standard approach that entrepreneurship programs typically take for business development. The strength of this approach is that it empowers beneficiaries by helping them come up with their own business ideas. The self-employed will choose ideas that match their skills and interests. In addition, they may have insight into local preferences and tastes, as well as cultural considerations. At the same time, however, it is also possible that beneficiaries end up participating in activities already saturated or economically nonviable if they lack a good understanding of market demands. The approach requires motivation and self-perception as an entrepreneur, notwithstanding that many self-employed might not see themselves as business people. And, even if sufficient applications are collected and business proposals are used as a screening method, if the quality of business ideas is low, the program is likely to fail.

For this model to reach out to more vulnerable and subsistence entrepreneurs, the following considerations in identifying viable business opportunities for support should be taken into account:

- Entrepreneurship awareness and sensitization should be a priority so that applicants see themselves as potential business people.

- Outreach activities need to be considered, as subsistence workers with limited social networks are the hardest group to reach.

- Applications should be simple, given the target group's lack of education and skills.

- Potential beneficiaries would need support in preparing these applications in selecting types of activity and requested services.

- There should be a mechanism to judge whether businesses/activities are economically viable; this is crucial in avoiding market saturation.

\subsubsection{Project identified}

In this case, the project identifies, ex ante, business opportunities through market and subsector mapping and demand surveys. The opportunities include both current activities that can be transformed to increase productivity and earnings, as well as new activities that could be introduced. In some cases, business opportunities can be flagged by the private sector. In others, an assessment would need to be conducted; this is usually part of a study of subsectors or value chains, and takes into account the availability of natural resources, infrastructure, regulatory environment, and human capital. The accuracy of such assessments has been debated, which should be taken into consideration.

In this model, participants are expected to develop their businesses within the context of the parameters selected by the project. Given participants' lack of entrepreneurial traits and ability to develop business ideas, this approach likely has advantages in serving the needs of the less capable entrepreneurs. In addition, this approach, despite its complexity compared to the participant-driven one, holds promise for potential impacts on a large scale. 
Table 2 Examples of participant-driven models

\begin{tabular}{|c|c|c|c|c|c|}
\hline Model & General description & $\begin{array}{l}\text { Main constraints } \\
\text { addressed }\end{array}$ & $\begin{array}{l}\text { Implementation } \\
\text { considerations }\end{array}$ & $\begin{array}{l}\text { Modifications for very vulnerable/self- } \\
\text { employed }\end{array}$ & Project examples \\
\hline \multirow{4}{*}{$\begin{array}{l}\text { Technical } \\
\text { Training Model } \\
\text { with } \\
\text { Entrepreneurship } \\
\text { Track }\end{array}$} & \multirow{4}{*}{$\begin{array}{l}\text { Technical or vocational training model that } \\
\text { offers entrepreneurship support or a separate } \\
\text { track for those interested }\end{array}$} & \multirow{4}{*}{$\begin{array}{l}\text { Technical/vocational } \\
\text { skills as well as } \\
\text { business skills }\end{array}$} & \multirow{3}{*}{$\begin{array}{l}\text { Training model does not lend } \\
\text { itself to advisory and } \\
\text { networking services }\end{array}$} & Inclusion of literacy and numeracy & AGI Liberia, Nepal \\
\hline & & & & Psycho-social support & \multirow{3}{*}{$\begin{array}{l}\text { Vocational Training for youths } \\
\text { with Disabilities in Western } \\
\text { Area and Kono Districts, Sierra } \\
\text { Leone }\end{array}$} \\
\hline & & & & Business idea generation and support & \\
\hline & & & $\begin{array}{l}\text { Duration of training should } \\
\text { consider skill sufficiency for } \\
\text { self-employment }\end{array}$ & $\begin{array}{l}\text { Access to finance, networks, and advisory } \\
\text { services need to be included }\end{array}$ & \\
\hline \multirow[t]{3}{*}{$\begin{array}{l}\text { One Stop Shop/ } \\
\text { Service Window }\end{array}$} & \multirow{3}{*}{$\begin{array}{l}\text { Training, finance, advisory and networking } \\
\text { services available on demand, often through } \\
\text { referral. Services are requested via a business } \\
\text { idea or plan. }\end{array}$} & \multirow{3}{*}{$\begin{array}{l}\text { Dependent on } \\
\text { services provided and } \\
\text { beneficiary } \\
\text { needs—customized }\end{array}$} & \multirow{2}{*}{$\begin{array}{l}\text { One-on-one advising to } \\
\text { create business services } \\
\text { package for each beneficiary }\end{array}$} & \multirow{2}{*}{$\begin{array}{l}\text { An intermediation, hands-on approach, } \\
\text { rather than light advising, is likely needed, } \\
\text { with much more guidance and idea } \\
\text { generation }\end{array}$} & $\begin{array}{l}\text { Women Entrepreneurship } \\
\text { Development Project, Ethiopia }\end{array}$ \\
\hline & & & & & \multirow{2}{*}{$\begin{array}{l}\text { Self-Employed Women's } \\
\text { Association Community } \\
\text { Learning Centers, India }\end{array}$} \\
\hline & & & $\begin{array}{l}\text { Considerable linkages to } \\
\text { other programs and } \\
\text { institutions necessary to have } \\
\text { sufficient services }\end{array}$ & $\begin{array}{l}\text { Linkage to social services/psychosocial } \\
\text { support }\end{array}$ & \\
\hline
\end{tabular}


Value chains-also referred to as subsectors, clusters, or supply chains-are relevant for SSE programs for two reasons. First, many producers, particularly in farm and nonfarm activities, are connected in one way or another to these chains. In these cases, horizontal (between channels) or vertical movements within the chain can lead to gains in productivity and earnings. Second, for certain producers of tradable goods and services who are only operating in local markets, connecting to one of these subsectors can be an opportunity to expand sales and earnings. In fact, identifying the right value chains could be a precondition to make SSE programs viable and avoid saturating local markets and bringing down prices and earnings.

Two important processes need to be considered when integrating SSE programs into value chains: (1) mapping the relevant subsectors, and (2) identifying the types of interventions needed to increase earnings (usually by reducing costs, improving quality, and/or increasing productivity).

Mapping the relevant subsectors: there are several methods and instruments to map markets. These methods are often based on interviews with key informants to identify the main actors, their interactions, and their consumption and supply of different products. These specialized assessments are usually conducted by management consultants, trade associations, business development service agencies, and NGOs. It is important to note, however, that while in many assessments the entry point is a given product in a sector, in SSE programs the value chains would need to be selected/designed to be accessible to the target population of beneficiaries. In all cases, many producers of the same goods and services would need to be brought together-primarily because it is often through aggregation that the correct scale of the business can be achieved to compete within a given value chain. Also, aggregation through associations, cooperatives, and firms reduces contact costs, because the program does not have to coordinate with businesses individually.

Identifying interventions to create jobs and/or increase earnings: once the business areas to be aggregated and the relevant value chains have been identified, various alternative interventions are possible. These will usually focus on one or more of the following: connecting beneficiaries to the value chains; improving production technologies to improve quality, reduce costs, and/or increase productivity; facilitating vertical or horizontal movements within the value chain; or collectively addressing bottlenecks and regulatory failures. The challenge is to get skills up to the quality standards required by the value chain and to identify viable business for the group. Traditionally, the value chain approach has mostly sought to address the constraints of those already in the value chain, or at its margins. To this end, it is important to identify a value chain that does not only have a high potential for increased productivity, but already includes targeted groups. When trying to integrate new actors (the self-employed) into a value chain, a comprehensive approach that includes entrepreneurship sensitization and business and technical skills development is needed.

The project-identified approach includes value chain integration and microfranchising (see Table 3 for examples). Common features across different models are that the project selects a potentially lucrative subsector or industry for intervention, involves a large number of individuals, facilitates the building of group-based social capital, and promotes public-private partnership. The value chain approach 
Table 3 Examples of project-identified models

\begin{tabular}{|c|c|c|c|c|c|}
\hline Model & General description & $\begin{array}{l}\text { Constraints } \\
\text { addressed }\end{array}$ & $\begin{array}{l}\text { Implementation } \\
\text { considerations }\end{array}$ & $\begin{array}{l}\text { Specifications for } \\
\text { very vulnerable/ } \\
\text { self-employed }\end{array}$ & Examples \\
\hline \multirow[t]{6}{*}{$\begin{array}{l}\text { Value } \\
\text { chain } \\
\text { approach }\end{array}$} & \multirow{6}{*}{$\begin{array}{l}\text { Refers to all activities } \\
\text { and services that } \\
\text { bring a product (or } \\
\text { service) from } \\
\text { conception to end } \\
\text { use in a particular } \\
\text { industry. The focus is } \\
\text { on the system, on } \\
\text { end markets, and on } \\
\text { relationships. An } \\
\text { opportunity exists to } \\
\text { integrate the self- } \\
\text { employed that have } \\
\text { been catering to the } \\
\text { local market. }\end{array}$} & $\begin{array}{l}\text { Access to } \\
\text { markets and } \\
\text { networks }\end{array}$ & $\begin{array}{l}\text { Mapping a value } \\
\text { chain is time } \\
\text { intensive and costly }\end{array}$ & $\begin{array}{l}\text { Aggregated } \\
\text { businesses are } \\
\text { often necessary } \\
\text { for farmers/self- } \\
\text { employed to } \\
\text { access a value } \\
\text { chain }\end{array}$ & $\begin{array}{l}\text { Green World } \\
\text { Bayer Crop } \\
\text { Science }\end{array}$ \\
\hline & & $\begin{array}{l}\text { Information } \\
\text { asymmetries }\end{array}$ & $\begin{array}{l}\text { Extensive relationship } \\
\text { building required }\end{array}$ & $\begin{array}{l}\text { Technical skills } \\
\text { and quality must } \\
\text { be upgraded }\end{array}$ & \multirow[t]{5}{*}{ Technoserv } \\
\hline & & $\begin{array}{l}\text { Transportation } \\
\text { constraints }\end{array}$ & \multirow{4}{*}{$\begin{array}{l}\text { Because the focus is } \\
\text { on a specific sector } \\
\text { and value chain, it } \\
\text { might exclude some } \\
\text { beneficiaries, due to } \\
\text { industry needs }\end{array}$} & \multirow{2}{*}{$\begin{array}{l}\text { Curricula may } \\
\text { need to be } \\
\text { modified for lack } \\
\text { of literacy }\end{array}$} & \\
\hline & & $\begin{array}{l}\text { Access to } \\
\text { input markets }\end{array}$ & & & \\
\hline & & $\begin{array}{l}\text { Business idea } \\
\text { generation }\end{array}$ & & \multirow{2}{*}{$\begin{array}{l}\text { Inclusion of } \\
\text { literacy and } \\
\text { numeracy } \\
\text { training, as well as } \\
\text { psycho-social } \\
\text { support }\end{array}$} & \\
\hline & & $\begin{array}{l}\text { Product } \\
\text { quality }\end{array}$ & & & \\
\hline \multirow[t]{6}{*}{$\begin{array}{l}\text { Micro- } \\
\text { franchising }\end{array}$} & \multirow{6}{*}{$\begin{array}{l}\text { Package interventions } \\
\text { that provide } \\
\text { beneficiaries with } \\
\text { comprehensive } \\
\text { support to enable } \\
\text { them to replicate } \\
\text { existing and proved } \\
\text { business model and } \\
\text { product. } \\
\text { Microfranchise } \\
\text { opportunities allow } \\
\text { self-employment with } \\
\text { features of wage em- } \\
\text { ployment: the micro- } \\
\text { franchisees do not } \\
\text { need to devise busi- } \\
\text { ness models of their } \\
\text { own but have min- } \\
\text { imal supervision. }\end{array}$} & $\begin{array}{l}\text { Reduces risk } \\
\text { from potential } \\
\text { entrepreneurs }\end{array}$ & $\begin{array}{l}\text { Limited business } \\
\text { scalability in any } \\
\text { given sector }\end{array}$ & $\begin{array}{l}\text { Inclusion of } \\
\text { literacy and } \\
\text { numeracy } \\
\text { training, as well as } \\
\text { psycho-social } \\
\text { support }\end{array}$ & $\begin{array}{l}\text { Coca Cola } \\
\text { manual } \\
\text { distribution } \\
\text { centers }\end{array}$ \\
\hline & & $\begin{array}{l}\text { Low business } \\
\text { knowledge/ }\end{array}$ & \multirow{5}{*}{$\begin{array}{l}\text { Costs associated with } \\
\text { product advances } \\
\text { lost or damaged, and } \\
\text { product } \\
\text { dissemination }\end{array}$} & $\begin{array}{l}\text { Basic accounting } \\
\text { skills }\end{array}$ & \multirow{5}{*}{$\begin{array}{l}\text { Girls } \\
\text { Empowered } \\
\text { by Micro } \\
\text { Franchise } \\
\text { International } \\
\text { Rescue } \\
\text { Committee }\end{array}$} \\
\hline & & \multirow{2}{*}{$\begin{array}{l}\text { Liquidity often } \\
\text { addressed } \\
\text { through } \\
\text { product } \\
\text { advances }\end{array}$} & & $\begin{array}{l}\text { Customer service } \\
\text { skills }\end{array}$ & \\
\hline & & & & \multirow[t]{3}{*}{ Pricing support } & \\
\hline & & $\begin{array}{l}\text { Business idea/ } \\
\text { product } \\
\text { generation }\end{array}$ & & & \\
\hline & & $\begin{array}{l}\text { Vertical } \\
\text { networking }\end{array}$ & & & \\
\hline
\end{tabular}

works with an identified value chain in an industry (e.g., coffee, tourism, or marble). Ideally, selection of the value chain is based on opportunity for growth or a significant reduction in inefficiencies, and integrates self-employed individuals and businesses up and down the value chain into the intervention. An example of this approach is TechnoServe's Coffee Initiative, started in 2007. This value chainstrengthening program helps small-scale coffee farmers in East Africa boost their incomes by improving the quantity and quality of coffee produced. The project aims to increase yields through extension and training in good agricultural practices and to improve quality by helping farmers establish and operate rural processing facilities ("wet mills"). The model enables achievement of these goals through horizontal integration of the farmers involved and better management of cooperatives, improved quality of the coffee produced, installation of coffee wet 
mill facilities, the establishment and strengthening of market linkages between the cooperatives and the national value chains, and improving the enabling environment for coffee industry producers.

\subsection{Defining core interventions}

As discussed, four types of services characterize SSE programs: training of various types, access to capital and other financial services, advisory services, and networking. Given a potentially highly heterogeneous group of beneficiaries and evidence of the effectiveness of comprehensive programs, it is unlikely that successful SSE programs could focus on only one of these services. The findings indicate that the correct strategy is to offer an integrated package of services tailored to beneficiary needs. A good profiling system for beneficiaries is therefore a precondition to structure the package of services and avoid offering "offthe-shelf" benefits.

\subsubsection{Training}

A general principle with regard to training services in SSE programs is to ensure that basic skills are acquired before moving up to higher-level skills (Fig. 5). Gaps in literacy and numeracy within the population of beneficiaries should be prioritized as this could be a primary barrier to other skills acquisition. ${ }^{18}$ Entrepreneurial awareness is a set of skills training that enables subsistence farmers, indigenous groups, and other vulnerable self-employed to begin seeing themselves, and acting, as business people-an important prerequisite to the development of business skills. In the same vein, basic financial literacy can help individuals better manage their limited resources. Although few SSE programs currently offer this type of training, it could be one of the most relevant among the low-skilled self-employed. These basic skills should be followed by technical skills and advanced business skills. For each skill level, training in a complementary set of soft skills-ranging from fostering confidence to improving negotiation-needs to be implemented in order to improve effectiveness.

\subsubsection{Financial services}

The goal in providing financial services is to ensure that beneficiaries are able to fund working capital and equipment, and have access to the relevant types of insurance to protect incomes and equipment, and cope with work-related accidents. In general, provision of these services is beyond the scope of SSE programs. Instead, such programs would need to facilitate access to financial institutions that offer these services (e.g., microfinance institutions). Rather than simply linking individuals with institutions, programs should consider incorporating arrangements to ensure that the necessary services are actually obtained. These arrangements could include assistance with applications, loan guarantees, and creditworthiness assessment, ${ }^{19}$ which will likely entail working with both individuals and financial institutions.

When it comes to funding working capital and equipment, an alternative to credit is to provide grants in cash and/or in kind. Grants would increase the cost 


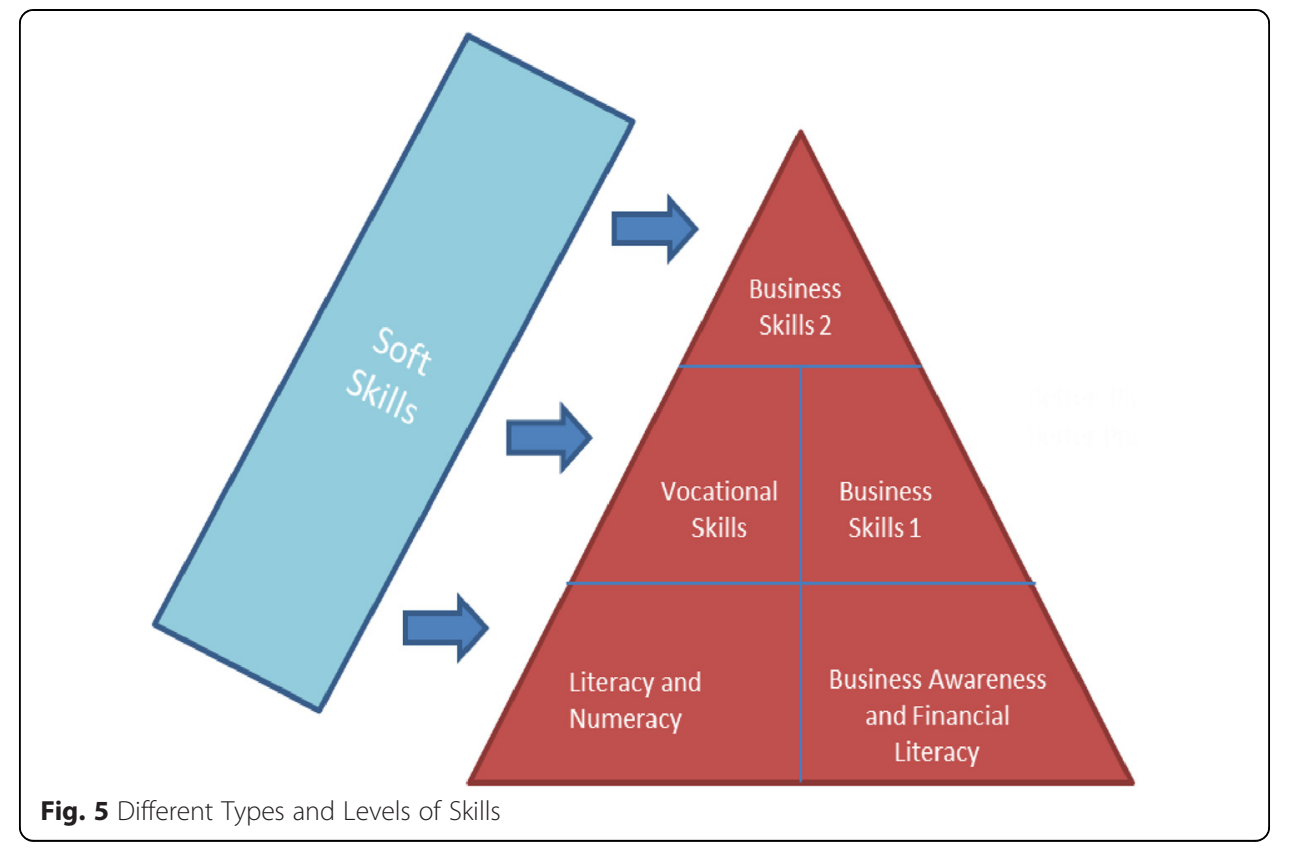

of the program, but might be easier to administer while giving cash-strapped beneficiaries more financial flexibility. Another alternative is crowdfunding, which was used in a very small number of the reviewed programs; loan guarantees might also facilitate access. These innovations should be developed further and rigorously tested.

\subsubsection{Advisory services and networking}

Unlike training programs which are offered at a given point in time and have a finite duration, advisory services are typically offered on a continuous basis, at least during the first stages of program implementation. These services can take various forms, from very hands-on to on demand only, virtual or face to face, and/or one to one or one to many (through information and communication technology). The advisors can be experts in the subsector or other entrepreneurs or producers. Their basic role is to answer questions about any aspect of the business or refer the beneficiary to the proper source. They could also be involved in monitoring implementation of different activities and intervene when they feel corrections are needed. Many agricultural projects rely on lead farmers who receive extensive training on new techniques, products, and quality measures, or on business skills to disseminate what they learn to a community of farmers. Other projects use government extension services or more professional advisors. The right type of advisory services to offer will also depend on local conditions and business needs; multiple options could be offered. In addressing the needs of the vulnerable selfemployed, face-to-face and more hands-on approaches might be the best options. Such approaches might require having advisors on the ground who monitor activities and are on call to help beneficiaries when needed. Over time, as beneficiaries gain experience in the implementation of their activities and/or the 
management of their business, some of them could gradually begin to take on advisory responsibilities and help new entrants to the program.

Networking services can take a number of forms as well. Theoretically, networking services create two types of linkages:

- Horizontal linkages. These describe relationships between participants operating at the same stage of production. Horizontal linkages include associations, cooperatives, and other forms of cooperation between potential competitors. For example, farmers who establish a formal or informal association in order to sell their products in larger quantities to a wholesaler would strengthen their horizontal linkages. Another example is labor unions of service providers or manufacturers.

- Vertical linkages. These describe relationships between participants with adjacent roles who potentially add value to the same product at different stages of production. Vertical linkages may include buying, selling, or contracting arrangements throughout the chain. For example, a farmer gaining access to a wholesaler will strengthen vertical linkages, as will a shoemaker who is connecting to a leather supplier. Vertical linkages do not include supporting service providers such as banks or insurance companies, as these do not directly add value to a product itself.

While horizontal linkages are often facilitated through SSE programs, few programs include vertical linkages. The value chain inclusion model discussed above has great potential in creating vertical linkages.

\subsubsection{Choosing delivery options}

The type of institutional arrangements needed to execute the various business processes described above-profiling and assessing the constraints facing beneficiaries, assessing market demand for nontradable goods and services, mapping subsectors and value chains, and offering various types of services-is an important policy consideration. Four actors comprise the main institutional choices: government, the private sector (for profit), NGOs and social entrepreneurs, and civil society (Table 4).

Table 4 Suggested implementation arrangements

\begin{tabular}{|c|c|c|c|c|c|c|}
\hline Actor & $\begin{array}{l}\text { Identification, } \\
\text { targeting, } \\
\text { profiling }\end{array}$ & $\begin{array}{l}\text { Assessing market } \\
\text { and mapping } \\
\text { opportunities }\end{array}$ & $\begin{array}{l}\text { Selecting } \\
\text { businesses }\end{array}$ & $\begin{array}{l}\text { Identifying } \\
\text { services }\end{array}$ & $\begin{array}{l}\text { Delivering } \\
\text { services }\end{array}$ & $\begin{array}{l}\text { Management and } \\
\text { monitoring and } \\
\text { evaluation }\end{array}$ \\
\hline $\begin{array}{l}\text { Government } \\
\text { (social) }\end{array}$ & +++ & & & ++ & & +++ \\
\hline $\begin{array}{l}\text { Government } \\
\text { (industry) }\end{array}$ & & ++ & ++ & ++ & + & \\
\hline Private sector & & +++ & +++ & +++ & ++ & \\
\hline $\begin{array}{l}\text { NGOs/social } \\
\text { entrepreneurs }\end{array}$ & & +++ & +++ & +++ & +++ & ++ \\
\hline $\begin{array}{l}\text { Communities/ } \\
\text { civil society }\end{array}$ & ++ & + & ++ & ++ & + & + \\
\hline
\end{tabular}


Governments would need to take the lead in the conceptualization, design, financing, supervision, and evaluation of SSE programs. More established organizations such as large enterprises and sector associations can facilitate win-win opportunities by collaborating with relevant subsectors and smaller partners. A large credit card company in the Republic of Korea, for instance, built infrastructure for traditional vendors with local government coordination. Part of the infrastructure included equipment for financial transactions and a credit card processor. Some NGOs and groups of social entrepreneurs (e.g., Ashoka) have developed an expertise in mapping or developing subsectors in low-income settings-including through the organization of international competitions to find the best ideas to solve a problem or develop a business. NGOs could also play an important role, along with the for-profit private sector, in service provision. Communities and civil society can play a critical role in identifying and mobilizing beneficiaries, assessing business opportunities and needs, and monitoring and evaluation.

\section{Concluding remarks}

Self-employment is the most common type of employment worldwide-and for many, the only alternative. A majority of the self-employed-farmers and own-account workers-are engaged in very low-productivity activities and live in poor households. Simply relinquishing the self-employed to social safety nets may not be sufficient to improve their standards of living-particularly since wage employment is not an option for many of these people. Programs that support the self-employed and small-scale entrepreneurs in improving their livelihoods are therefore an important complementary intervention.

Unfortunately, limited evidence exists regarding the impact and effectiveness of these programs, as well as the best way to design and implement them. Most of the programs that have been evaluated are small pilots, and the results are mixed. There are also questions about the external validity of these results and whether results would persist if programs were scaled up.

Governments need to continue experimenting with SSE programs targeted to subsistence entrepreneurs. A more systematic and rigorous approach to their design, implementation, and evaluation should be adopted. Research and policy analysis should focus on profiling instruments to improve understanding of beneficiary characteristics and constraints, mechanisms to identify business opportunities, guidelines to design and combine interventions tailored to different beneficiaries, the effectiveness of various implementation arrangements, and intervention cost-effectiveness and sustainability.

\section{Endnotes}

${ }^{1}$ The poverty line is defined as $\$ 2$ per day for per capita household consumption.

${ }^{2}$ The self-employed are a heterogeneous group of individuals. Some become entrepreneurs as they accumulate sufficient wealth to relax liquidity constraints and to create profitable investment with appropriate skills to operate businesses (Evans and Jovanovic, 1989; Falco and Haywood, 2013). On the other hand, subsistence entrepreneurs become self-employed by necessity when no other employment opportunities (e.g., formal wage employment) are available for them (Poschke, 2013). 
${ }^{3}$ Other types of entrepreneurs can be further disaggregated into vocational and transformational entrepreneurs, where vocational entrepreneurs are those who choose entrepreneurial activities and business as a vocation, but who likely lack the desire or ability to grow a business, whereas transformational entrepreneurs are high-growth, innovative, and expansive entrepreneurs who are likely to have entrepreneurial traits.

${ }^{4}$ The International Income Distribution Data Set (I2D2) is a global harmonized household survey database. It includes a basic set of harmonized variables that are comparable across country and time.

${ }^{5}$ The propensity for a worker to be an employer or own-account worker is estimated using observable characteristics such as age, education, or sector of employment; this serves a basis for similarity/difference in characteristics in Cho et al. (2014); Grimm et al. (2012); and Gindling and Newhouse (2014).

${ }^{6}$ See Cho et al. (2014).

${ }^{7}$ For instance, Grimm et al. (2012) defined 10 percent of business owners as "top performers," based on their accumulated capital and its profitability. The likelihood of being a top performer increases with characteristics such as age, education, and "entrepreneurial spirit." The researchers then obtained the propensity to be successful and find those who have similar success propensity among unsuccessful ones (so-called "constrained gazelles"). Thus, high performers, constrained gazelles and entrepreneurs with low potential coexist in the market.

${ }^{8}$ See Pierre et al. (2014) and Valerio et al. (2014c) for the summary methodology and findings from the STEP skills measurement surveys.

${ }^{9}$ See van Bastelaer (2000) for a review.

${ }^{10}$ See Valerio et al. 2014a for more information on the database: http://hdl.handle.net/10986/18031.

${ }^{11}$ The database is a comprehensive inventory of programs promoting youth employment. The inventory was an outcome of joint efforts of the German Ministry of Economic Cooperation and Development (BMZ), the Inter-American Development Bank (IADB), the International Labour Organization (ILO), World Bank and Youth Employment Network (YEN). From the database, projects with a focus on entrepreneurship were selected for this paper. http://www.youth-employment-inventory.org

${ }^{12}$ Only about 5 percent of the projects in the inventory are provided as a poverty reduction or livelihood program for the poor, while the remaining majority broadly targets existing or potential entrepreneurs for their innovation.

${ }^{13}$ For more information on program costs, see Valerio et al. (2014b).

${ }^{14}$ In Sri Lanka, the returns to capital for men range from 6.5 to 14 percent while the returns for women were close to none; Similarly, in Ghana, the returns to capital for men were up to 26 percent while for women there were no gains.

${ }^{15}$ Fafchamps et al. 2011 found that in-kind support yielded greater impacts than cash grants for women often due to household consumption when cash was provided.

${ }^{16}$ See programs details from http://go.worldbank.org/5PYHEZS360

${ }^{17}$ Some frequently used instruments to profile individuals and assess constraints can be found in the Additional file 1 .

${ }^{18}$ The African Youth Report documents that primary education can lead to 40 percent increases in earnings for the self-employed.

${ }^{19}$ In Ethiopia, an SSE program uses psychometric testing to assess the creditworthiness of individuals and facilitate their access to financial institutions. 


\section{Additional file}

Additional file 1: Assessing constraints to self-employment and small-scale entrepreneurship.

\section{Competing interest}

The IZA Journal of Labor Policy is committed to the IZA Guiding Principles of Research Integrity. The authors declare that they have observed these principles.

\section{Acknowledgement}

This paper has been prepared as a part of broader "entrepreneurship project" at the Social Protection and Labor Unit, World Bank, Washington DC. The findings, interpretations, and conclusions expressed here are personal and should not be attributed to the World Bank, its management, its Executive Board of Directors, or any of its member countries. We thank two anonymous reviewers for their valuable comments. Useful inputs and suggestions were provided throughout the project by Xavier Cirera, Leonardo lacovone, and Esperanza Lasagabaster. The authors also thank Graham Dixie, Sukanya Garg, Hyewon Kang, David Margolis, and Marta Malgorzata Milkowska for their contributions. The World Bank Education Team, led by Alexandria Valerio, provided invaluable input through the provision of data from their Entrepreneurship Education and Training database which accounts for half of the inventoried programs in this paper. Helpful comments were received from Mary Hallward-Driemeier, Cem Mete, Jamele Rigolini, Dena Ringold, Rita Almeida, Louise Fox, Mattias Lundberg, Iftikhar Malik, Lucian Pop, Patrick Premand, Maria Laura Sanchez Puerta, and conference participants at the 9th IZA/World Bank Conference on Employment and Development in Lima, Peru. Responsible editor: David Neumark.

\section{Author details}

${ }^{1}$ World Bank and IZA, 1818 H St NW, Washington, DC 20433, USA. "World Bank, 1818 H St NW, Washington, DC 20433, USA.

Received: 7 February 2015 Accepted: 4 January 2016

Published online: 13 April 2016

\section{References}

Ashraf N, Fink G, Weil D (2010) Evaluating the effects of large scale health interventions in developing countries: the Zambian malaria initiative, NBER working paper 16069

Ashraf N, Karlan D, Yin W (2010) Female empowerment: impact of a commitment savings product in the Philippines. UniversityWorld Dev. 38(3): 333-344

Bauchet J, C Marshall, L Starita, J Thomas, A Yalouris (2011) Latest Findings from Randomized Evaluations of Microfinance. CGAP

Blattman C, Fiala N, Martinez S (2014) Generating skilled self-employment in developing countries: experimental evidence from Uganda: Q J Econ 129(2): 697-752.

Bloom N, Van Reenen J (2007) Measuring and explaining management practices across firms and countries. Q J Econ 122(4):1341-1408

Bloom N, Van Reenen J (2010) Why do management practices differ across firms and countries? J Econ Perspect 24:1

Bruhn M, Karlan D, Bowen HP, De Clercq D (2010) Institutional context and the allocation of entrepreneurial effort. J Int Bus Stud 39:747-767

Cho Y, Honorati M (2014) Entrepreneurship programs in developing countries: a meta-regression approach. Labour Econ 28:110-130

Cho Y, Robalino, Romero (2014) Entering and Leaving Self Employment: An Analysis of Panel Data in 12 Developing Countries. Mimeo, World Bank, Washington DC

Cho Y, Kalomba D, Mobarak AM, Orozco V (2013) Gender differences in the effects of vocational training: constraints on women and drop-out behavior., IZA discussion paper, \#7408

Conley T, Udry C (2010) Learning about a New technology: pineapple in Ghana. Am Econ Rev 100:1

de Mel S, McKenzie D, Woodruff C (2008) Who are the microenterprise owners: evidence from Sri Lanka on Tokman v. de Soto, Bureau for Research in Economic Analysis of Development (BREAD) Working Paper No. 174

de Mel S, McKenzie D, Woodruff C (2009) Are women more creidt constrained? experimental evidence on gender and microenterprise returns. Am Econ J 1(3):1-32

Develi El (2011) Entrepreneurship and importance of personality on entrepreneurship: a research on trainees of entrepreneurship education program. Int J Bus Manag Stud 3:1

Drexler A, Fischer G, Schoar A (2011) Keeping it simple: financial literacy and rules of thumb, Mimeo. Abdul Latif Jameel Poverty Action Lab (J-PAL) at MIT, Cambridge, MA

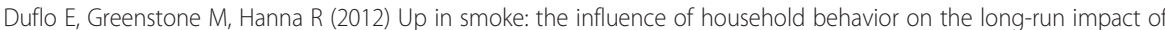
improved cooking stoves, MIT Department of Economics Working Paper 12-10., http://papers.ssrn.com/sol3/ papers.cfm?abstract_id=2039004. Accessed 19 January 2016

Duflo E, Kremer M, Robinson J (2011) Nudging farmers to use fertilizer: theory and experimental evidence from Kenya. Am Econ Rev 101(6):2350-2390

Evans D, Jovanovic B (1989) An estimated model of entrepreneurial choice under liquidity constraints. J Polit Econ 97(4):808-827, University of Chicago Press

Fafchamps M, Woodruff C (2012) Identifying Gazelles: Expert Panels vs. Survey as a Means to Identify Firms with Rapid Growth Potential, Mimeo, World Bank, Washington DC

Fafchamps M, McKenzie D, Quinn SR, Woodruff C (2011) When is capital enough to get female microenterprises growing? Evidence from a randomized experiment in Ghana, NBER Working Paper No. 17207 
Falco P, Haywood L (2013) Entrepreneurship versus joblessness: explaining the rise in self-employment, Discussion Papers of DIW Berlin 1334. German Institute for Economic Research, DIW Berlin

Gindling TH, Newhouse DL (2014) Self-employed in the developing world. World Dev 56(C):313-331

Gine X, Yang D (2009) Insurance, credit, and technology adoption: field experimental evidence from Malawi. J Dev Econ 89:1-11

Grimm M, Knorringa P, Lay J (2012) Constrained gazelles: high potentials in West Africa's informal economy. World Dev 40:7

Grimm M, Paffhausen AL (2015) Do interventions targeted at micro-entrepreneurs and small and medium-sized firms create jobs? A systematic review of the evidence for low and middle income countries. Labour Econ 32:67-85

Heckman JJ, Stixrud J, Urzua S (2006) The effects of cognitive and noncognitive abilities on labor market outcomes and social behavior. J Labor Econ 24:411-482

Holzmann R, Mulaj F, Perotti V (2013) Financial Capability in Low- and Middle-Income Countries: Measurement and Evaluation. World Bank, Washington DC.

Karlan D, Valdivia M (2011) Teaching entrepreneurship: impact of business training on microfinance clients and institutions. Rev Econ Stat 93(2):510-527

Macours K, Premand P, Vakis R (2012) Transfers, diversification and household risk strategies: experimental evidence with lessons for climate change adaptation, Policy Research Working Paper Series No. 6053. World Bank, Washington DC

McKenzie D, Woodruff C (2014) What are we learning from business training and entrepreneurship evaluations around the developing world. World Bank Res Obs 29(1):48-82

Mobarak AM, Rosenzweig MR (2012) Selling formal insurance to the informally insured., Yale University Economic Growth Center Discussion Paper 1007. doi:http://dx.doi.org/10.2139/ssrn.2009528

Nguimkeu P (2014) A structural econometric analysis of the informal sector heterogeneity. J Dev Econ 107(C):175-191, Elsevier

Pierre G, Sanchez-Puerta ML, Valerio A, Rajadel T (2014) STEP skills measurement surveys: innovative tools for assessing skills. World Bank, Washington, DC

Poschke M (2013) Who becomes an entrepreneur? Labor market prospects and occupational choice. J Econ Dyn Control 37(3):693-710

Rauch A, Frese M (2000) Psychological approaches to entrepreneurial success. A general model and an overview of findings. In: Cooper CL, Robertson IT (eds) International review of industrial and organizational psychology. Wiley, Chichester, pp 101-142

Stam W, Arzlanian S, Elfring T (2013) Social capital of entrepreneurs and small firm performance: a meta-analysis of contextual and methodological moderators. J Bus Ventur. http://dx.doi.org/10.1016/j.jbusvent.2013.01.002

Tushabomwe-Kazooba C (2006) Causes of small business failure in Uganda: a case study from Bushenyi and Mbarara towns. Afr Stud Q 8(4):27

Valerio A, Parton B, Robb A (2014a) Entrepreneurship education and training programs around the world: dimensions for success. World Bank, Washington DC

Valerio A, Parton B, Robb A (2014b) Global database of programs. World Bank, Washington DC, Entrepreneurship Education and Training Programs around the Word: Dimensions for Success

Valerio A, Sanchez Puerta ML, Pierre G, Rakade T, Monroy Taborda S (2014c) STEP skills measurement: snapshot 2014. World Bank, Washington DC

van Bastelaer T (2000) Imperfect information, social capital, and the Poor's access to credit, IRIS Center Working Paper No. 234. Center on Institutional Reform and the Informal Sector (IRIS), University of Maryland

\section{Submit your manuscript to a SpringerOpen ${ }^{\circ}$ journal and benefit from:}

- Convenient online submission

Rigorous peer review

- Immediate publication on acceptance

- Open access: articles freely available online

- High visibility within the field

- Retaining the copyright to your article 